\title{
INTEGRASI SISTEM HEADEND HFC PADA JARINGAN FIBER TO THE HOME UNTUK LAYANAN TV BROADCAST ANALOG
}

\section{INTEGRATION HFC HEADEND SYSTEM ON FIBER TO THE HOME NETWORK FOR BROADCAST ANALOG TV SERVICES}

\author{
Fiqri Fadlillah Mubarok ${ }^{1}$, Tri Nopiani Damayanti ${ }^{2}$, Dudung Ruhimat ${ }^{3}$ \\ ${ }^{1,2}$ Diploma 3 Teknik Telekomunikasi, Fakultas Ilmu Terapan, Universitas Telkom \\ ${ }^{3}$ Jabar Telematika \\ ${ }^{1}$ fadlillah.fiqri@gmail.com, ${ }^{2}$ damayanti@ telkomuniversity.ac.id, ${ }^{3}$ dudung.ruhimat@jatel.co.id
}

\begin{abstract}
Abstrak
Penelitian ini mengusulkan sebuah sistem headend Hybrid Fiber Coax (HFC) yang diintegrasikan pada jaringan Fiber to The Home (FTTH). Implementasi Headend HFC pada jaringan FTTH bertujuan untuk menambah layanan TV Broadcast Analog sehingga dengan menggunakan satu antenna dapat melayani banyak user dengan menggunakan panjang gelombang yang sama di $1550 \mathrm{~nm}$.

Implementasi jaringan yang diusulkan menggunakan perangkat FTTH meliputi perangkat OLT, ODC, passive splitter, patchcore, dan roset. Jaringan FTTH tersebut akan diintegrasikan dengan jaringan HFC dengan perangkat yang digunakan yaitu fiber transmitter, fiber node, tv tuner, antena, dan amplifier.

Hasil pengujian sistem menunjukkan bahwa nilai daya terima antena memiliki kualitas layanan yang baik dengan nilai sebesar $-40 \mathrm{~dB}$. Nilai sensitivitas penerimaan perangkat fiber node sebesar -5 dBm sampai dengan -27 dBm dengan nilai CNR yang dihasilkan sebesar -47.7 dB.
\end{abstract}

Kata kunci : Headead HFC, FTTH, Power Receive, CNR.

\section{Abstract}

This research has proposed a Hybrid Fiber Coax headend system (HFC) which is integrated in the Fiber to the Home (FTTH) network. HFC Headend Implementation on FTTH network aims to add Analog Broadcast TV service so that by using one antenna can serve many users by using the same wavelength at $1550 \mathrm{~nm}$.

The proposed network implementation using FTTH devices includes OLT, ODC, and passive splitter, patch core, and rosette devices. The FTTH network will be integrated with the HFC network with the devices used namely fiber transmitters, fiber nodes, tv tuners, antennas, and amplifiers

The system test results show that the antenna receive power value has good service quality with a value of $-40 \mathrm{~dB}$. The sensitivity value of the device receiving fiber node is $-5 \mathrm{dBm}$ up to -27 $\mathrm{dBm}$ with the resulting CNR value of $-47.7 \mathrm{~dB}$.

Keywords: Headead HFC, FTTH, Power Receive, CNR.

\section{PENDAHULUAN}

Teknologi Hybrid Fiber Coax (HFC) merupakan sebuah teknologi yang menggabungkan kabel serat optik dengan kabel koaksial untuk menyediakan layanan dengan laju data yang lebih tinggi dibandingkan menggunakan kabel koaksial. Layanan yang dapat disediakan oleh teknologi HFC saat ini sebagai broadband network antara lain TV Broadcast, internet, IP Telephony dan Video-On-Demand (VOD) [1-3]. Kebutuhan komunikasi yang menyediakan layanan broadband network dengan kapasitas bandwidth yang lebar semakin dibutuhkan oleh user. Teknologi jaringan 
yang dapat menyediakan kebutuhan layanan tersebut salah satunya adalah teknologi Passive Optical Network (PON). Teknologi PON telah diimplementasikan pada jaringan Fiber to The Home (FTTH), Fiber to The Building untuk menyediakan layanan triple play yaitu layanan internet, IPTV dan Telepon [4-7]. Pada jaringan FTTH yang saat ini telah diimplementasikan di Fakultas Ilmu Terapan Universitas Telkom, layanan IPTV untuk setiap user perlu menggunakan STB (Set Top Box) untuk dapat menerima layanan yang diberikan oleh operator dengan beberapa channel tertentu. Pada perkembangannya berdasarkan kebutuhan, dirasakan perlu adanya perangkat tambahan yang mampu menyediakan layanan TV Broadcast dengan channel pilihan sendiri dengan efisiensi perangkat di sisi user, low cost, serta dapat menampung user dalam jumlah yang banyak di Fakultas Ilmu Terapan Universitas Telkom.

Berdasarkan permasalahan diatas maka penelitian ini mengusulkan untuk mengintegrasikan sistem headend Hybrid Fiber Coax (HFC) pada jaringan FTTH Fakultas Ilmu Terapan Universitas Telkom. Headend memegang peranan penting dari sistem HFC. Fungsi utama headend adalah menerima dan memproses sinyal televisi baik yang broadcast maupun yang 'off-air' dan mendistribusikan sinyal tersebut (baik berupa sinyal video, audio maupun data) ke user.

\section{DASAR TEORI}

\subsection{Hybrid Fiber Coax (HFC)}

Jaringan HFC merupakan sebuah jaringan yang memadukan antara kabel koaksial dengan fiber optik menggunakan transmisi analog dengan metode Sub Carrier Multiplexing (SCM) yang dapat memberikan layanan internet, suara serta video [1]. Sinyal informasi yang ditransmisikan akan dirubah menjadi sinyal RF kemudian saat sinyal RF tersebut akan diubah menjadi sinyal yang akan ditransmisikan sampai ke fiber node. Pada perangkat fiber node, sinyal informasi yang telah diubah ke sinyal optik akan diubah kembali menjadi sinyal RF. Pada sisi user, sinyal RF akan dirubah kembali menjadi sinyal informasi..

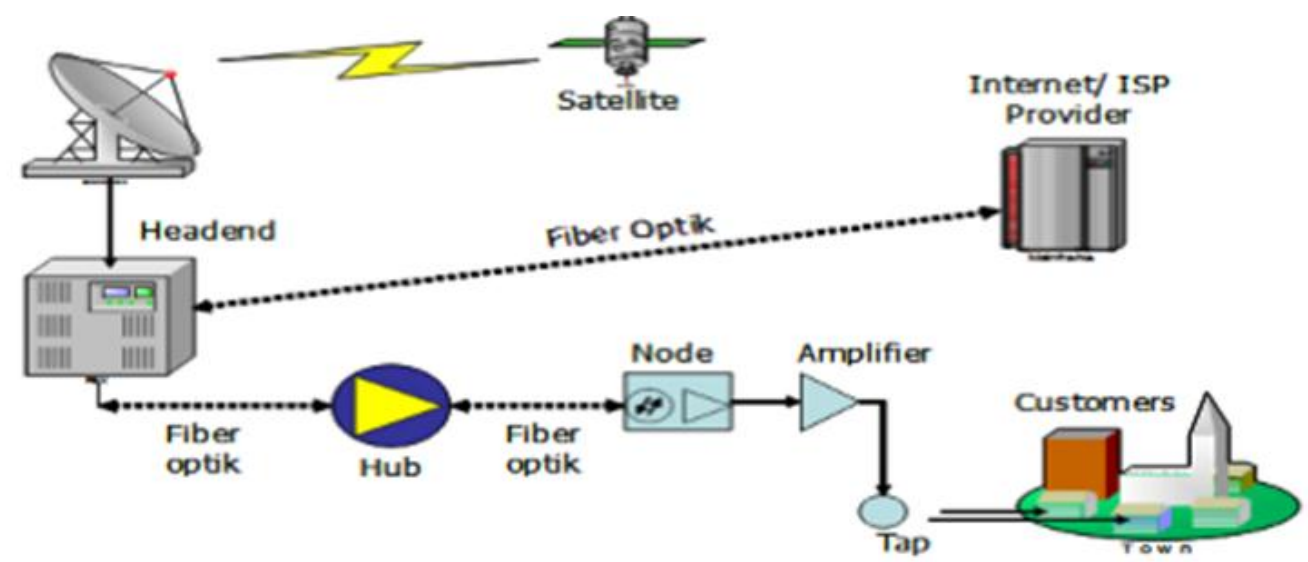

Gambar 1. Arsitektur HFC [8]

Pada arsitektur jaringan HFC yang ditunjukkan pada Gambar 1, terdapat beberapa perangkat pendukungnya antara lain Headend yang memiliki fungsi sebagai pengumpul dan pengolah sumber informasi yang akan didistribusikan ke user. Headend ini terdiri atas beberapa bagian yaitu receiver antenna, demodulator, modulator, combiner, cable router, dan opto elektronik.

Perangkat berikutnya yang digunakan pada jaringan HFC adalah fiber optik yang berfungsi untuk menghubungkan antara headend, distribution hub sampai dengan fiber node. Perangkat fiber node berfungsi untuk mengubah sinyal optik menjadi sinyal listrik yang akan ditransmisikan ke 
kabel koaksial atau sebaliknya. Perangkat selanjutnya adalah distribusi optik yang berfungsi untuk menghubungkan antara hub dengan fiber node. Perangkat HFC lainnya yaitu jaringan distribusi pelanggan merupakan jaringan akses untuk mendistribusikan sinyal RF dari fiber node menuju terminal pelanggan dan sebaliknya [8].

\subsection{Parameter Kualitas Jaringan HFC}

Faktor yang mempengaruhi performasi jaringan dinyatakan dalam perbandingan terhadap level daya sinyal pembawa. Parameter yang dapat diukur untuk menentukan kinerja jaringan akses HFC adalah Carrier to Noise Ratio (CNR). Nilai CNR merupakan nilai perbandingan antara level sinyal carrier dan level sinyal noise yang diterima receiver pada jaringan optik maupun jaringan kabel koaksial. Performasi noise dari perangkat tunggal ditetapkan sebagai noise figure. Nilai CNR yang direkomendasikan adalah 47 sampai dengan 49 dB [9]. Sedangkan standar CNR untuk performansi jaringan HFC berdasarkan ITU-T yakni $\geq 43 \mathrm{~dB}$ [10]. Nilai CNR jaringan pengaruh amplifier ditunjukkan pada persamaan 1 dan 2 [9]:

$$
\begin{aligned}
& C N R=65.2-10 \log ((\Delta f)+L i-N F) \\
& C N R=65.2-10 \log \left(V_{b}-N_{b}\right)+L i-N
\end{aligned}
$$

Dimana;

$\Delta \mathrm{f}=$ selisih antara video bandwidth dikurangi dengan noise bandwidth sesuai dengan sistem yang

digunakan $(\mathrm{MHz})$

$\mathrm{V}_{\mathrm{b}}=$ video bandwidth $(\mathrm{MHz})$

$\mathrm{NF}=$ Noise figure (noise dari perangkat tunggal)

$\mathrm{N}_{\mathrm{b}}=$ noise bandwidth $(\mathrm{MHz})$

$\mathrm{Li}=$ amplifier input level $(\mathrm{dBmV})$, dengan asumsi temperatur $68^{\circ} \mathrm{F}\left(20^{\circ} \mathrm{C}\right)$.

$\mathrm{N}=$ jumlah amplifier yang digunakan

\subsection{Fiber To The Home (FTTH)}

FTTH adalah jaringan broadband yang merupakan sistem jaringan yang mampu mentransmisikan video, data dan sinyal suara ke pengguna dengan tingkat kecepatan tinggi. FTTH menggunakan kabel serat optik sebagai media untuk sinyal transmisi kepada pengguna. Sebelum serat optik diimplementasikan ke dalam jaringan, kabel telepon tembaga digunakan untuk membawa sinyal yang dihasilkan oleh perangkat telepon. Jaringan FTTH tidak memerlukan komponen aktif dengan operasi yang rendah biaya untuk mematuhi permintaan pengguna. Bandwidth dari jaringan sangat penting dan akan menjadi faktor penentu dari kapasitas yang dapat dibawa. Semakin lebar bandwidth, semakin besar data yang dapat dibawa pada satu waktu [4].

\subsection{Wavelenght Division Multiplexing (WDM) PON}

Wavelenght Division Multiplexing (WDM) adalah teknologi multiplexing yang digunakan untuk menggabungkan beberapa sinyal informasi (suara, data, dan video) menjadi satu dengan menggunakan panjang gelombang cahaya yang berbeda-beda yang ditunjukkan pada Gambar 2 . Saat ini WDM banyak digunakan untuk meningkatkan kapasitas jaringan tanpa penambahan saluran optik baru. Penggunaan WDM dan penguat optik, user dapat mengakomodir perkembangan teknologi tanpa menambah infrastruktur jaringan backbone optik. Kapasitas dapat ditingkatkan secara mudah dengan mengembangkan multiplexer/demultiplexer disetiap sisi. Sedangkan untuk interoperability agar sistem dapat beroperasi menggunakan perangkat eksisting, maka pada 
jaringan transport dilakukan translasi dari optical to electrical to optical (O/E/O). WDM mengalokasikan satu sinyal optik dengan satu frekuensi cahaya atau panjang gelombang dalam frekuensi band tertentu. Teknik multiplexing ini serupa dengan teknik pada gelombang radio yang disaluran dengan frekuensi yang berbeda tanpa mengganggu satu sama lainnya. Pada sistem WDM, masing-masing panjang gelombang disalurkan ke dalam serat optik, dan sinyal di demultipleks di sisi penerima. WDM membawa masing-masing sinyal input secara terpisah, yang menginisialisasi tiap kanal memiliki dedicated bandwidth [11].

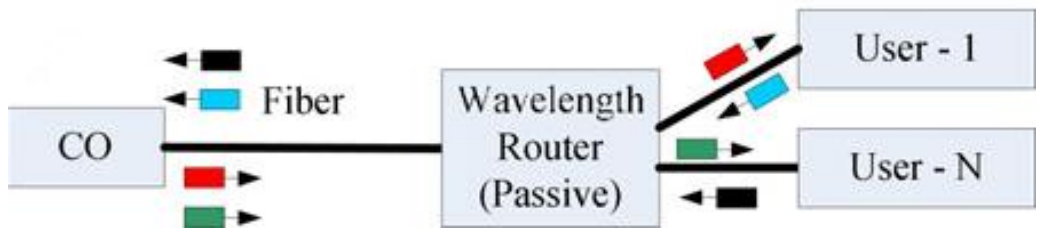

Gambar 2. Transmisi pada WDM PON [11]

\section{PEMBAHASAN DAN PENGUJIAN}

\subsection{Pemodelan Sistem}

Pemodelan sistem integrasi jaringan teknologi HFC dengan FTTH ditunjukkan pada gambar 3. Pada integrasi jaringan HFC - FTTH , antena akan menangkap sinyal channel dari Stasiun pemancar relay TV. Sebelum diolah di TV tuner, sinyal akan dikuatkan oleh amplifier dengan penguatan $10 \mathrm{~dB}$. Sinyal TV berupa sinyal baseband audio dan video akan ditempatkan pada sinyal pembawa RF oleh perangkat RF Modulator.

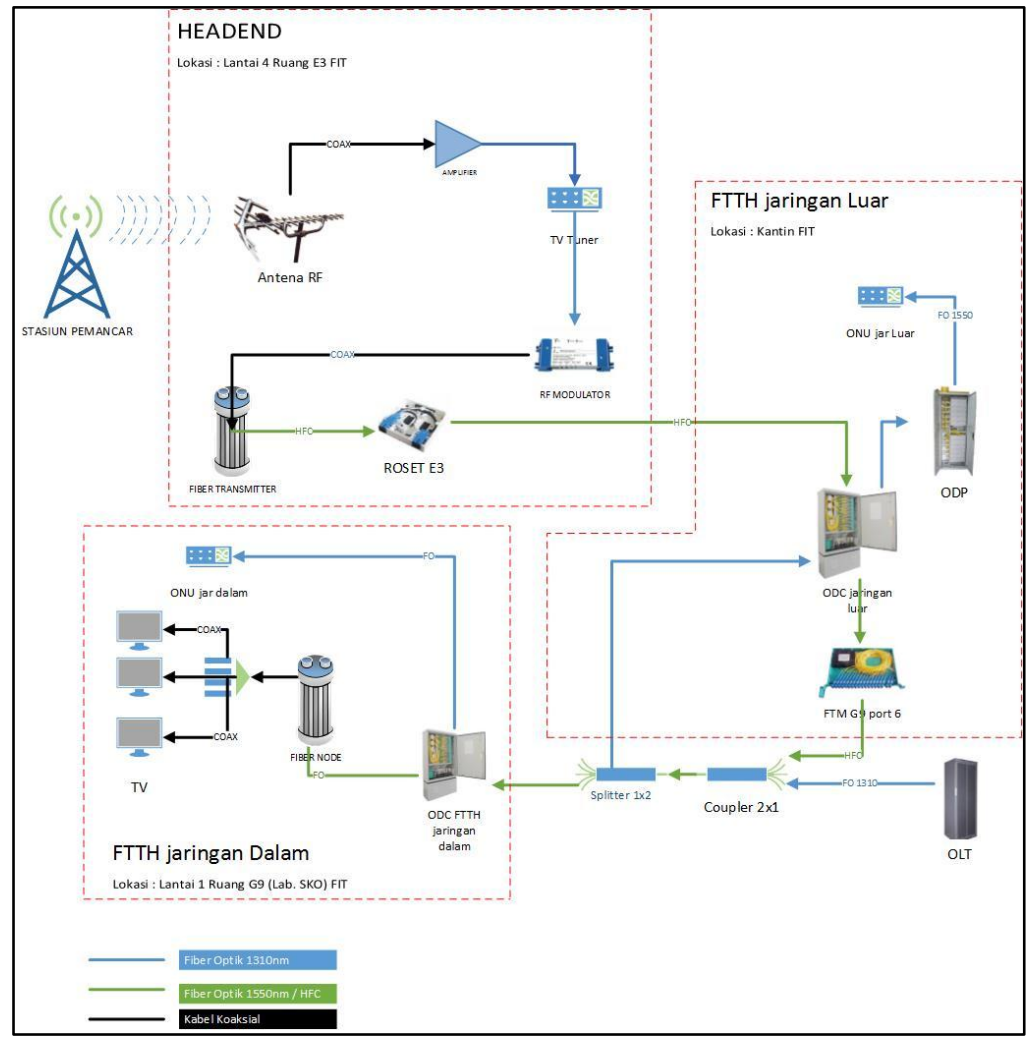

Gambar 3. Pemodelan Sistem Jaringan HFC-FTTH 
Sinyal RF akan dikonversi ke dalam bentuk sinyal optoelektronik dengan panjang gelombang $1550 \mathrm{~nm}$ untuk ditransmisikan menggunakan fiber optik melalui ODC jaringan luar/indoor dan FTM. Pada bagian FTM, jalur transmisi akan dimultiplex dengan input OLT dari FTM oleh coupler. Hasil multiplex akan ditransmisikan menggunakan jalur FTTH jaringan indoor. Sinyal akan ditransmisikan pada ODC melalui splitter untuk menghasilkan layanan Triple Play FTTH dan Layanan TV HFC hasil konversi ke bentuk RF di Fiber Node.

Pada implementasi ini, layanan yang digunakan adalah layanan TV analog dari antena penerima yang ditempatkan di area outdoor yang ditunjukkan pada Gambar 4.. Channel TV analog yang digunakan adalah channel TV lokal yang merupakan TV nasional dan TV daerah wilayah Bandung dan sekitarnya. Letak antena RF sangat berpengaruh terhadap jumlah channel dan kualitas yang dapat ditangkap. Letak antena harus memperhatikan kondisi gedung, kelurusan dengan derajat stasiun pemancar, dan estimasi panjang kabel koaksial sampai menuju amplifier. Pada implementasi ini, letak antena RF diletakkan di lantai 4 gedung Fakultas Ilmu Terapan.

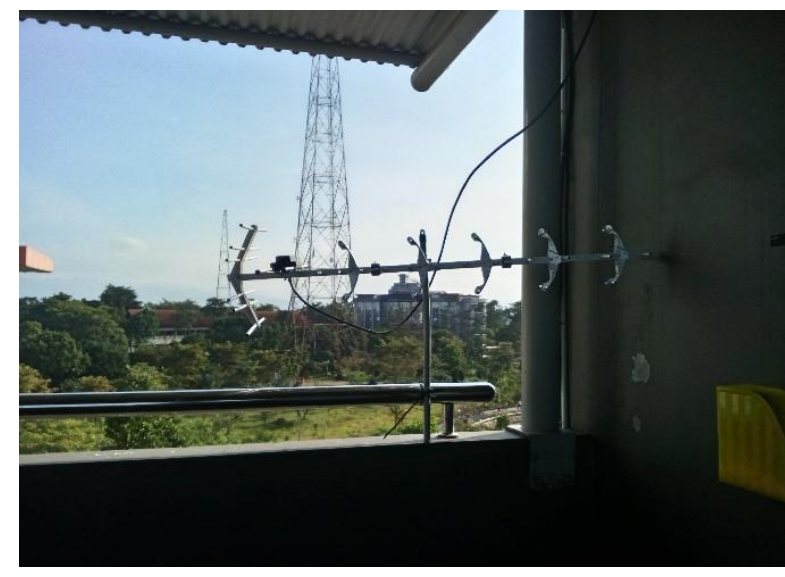

Gambar 4. Antena RF yang digunakan

Penempatan perangkat headend haruslah disesuaikan dengan range jarak kabel koaksial yang membawa siyal dari antena yakni $20 \mathrm{~m}$. Dalam hal ini, penepatan headend diletakkan ditunjukkan pada Gambar 5.

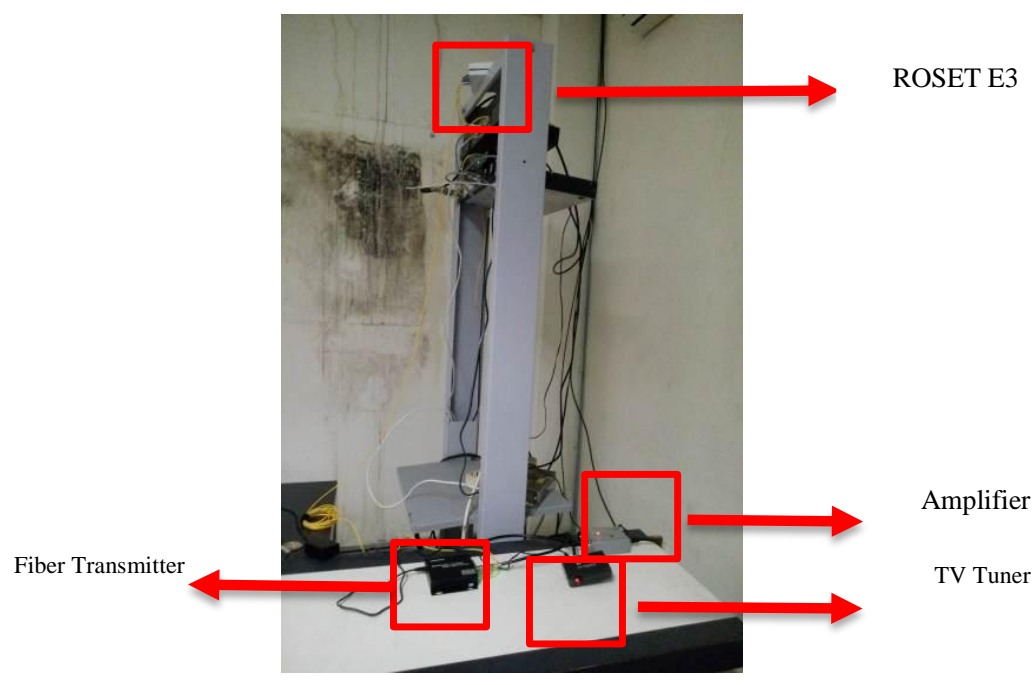

Gambar 5. Letak Headend 
Kebutuhan Perangkat HFC pada Jaringan FTTH ditunjukkan pada Tabel 1 berikut ini.

Tabel 1 Kebutuhan Perangkat HFC pada FTTH

\begin{tabular}{|l|c|c|}
\hline \multicolumn{1}{|c|}{ Perangkat } & Jumlah & Unit \\
\hline Antena & 1 & Buah \\
\hline TV Tuner & 1 & Buah \\
\hline CATV Amplifier & 1 & Buah \\
\hline Fiber Transmitter & 1 & Buah \\
\hline Fiber Node & 1 & Buah \\
\hline Kabel Koaksial RG6 & 20 & meter \\
\hline Patchcore FC APC & 2 & Buah \\
\hline OLT & 1 PON & Slot \\
\hline PS 1:2 & 2 & Buah \\
\hline PS 1:8 & 2 & Buah \\
\hline Coupler 2:1 & 1 & Buah \\
\hline Kabel fedeer & 150 & $\mathrm{~m}$ \\
\hline Kabel distribusi & 150 & $\mathrm{~m}$ \\
\hline
\end{tabular}

Pada ODC terdapat passive splitter 1:2 yang akan membagi kapasitas kabel menjadi beberapa output. Letak ODC jaringan indoor dan outdoor ditunjukkan pada Gambar 6 .

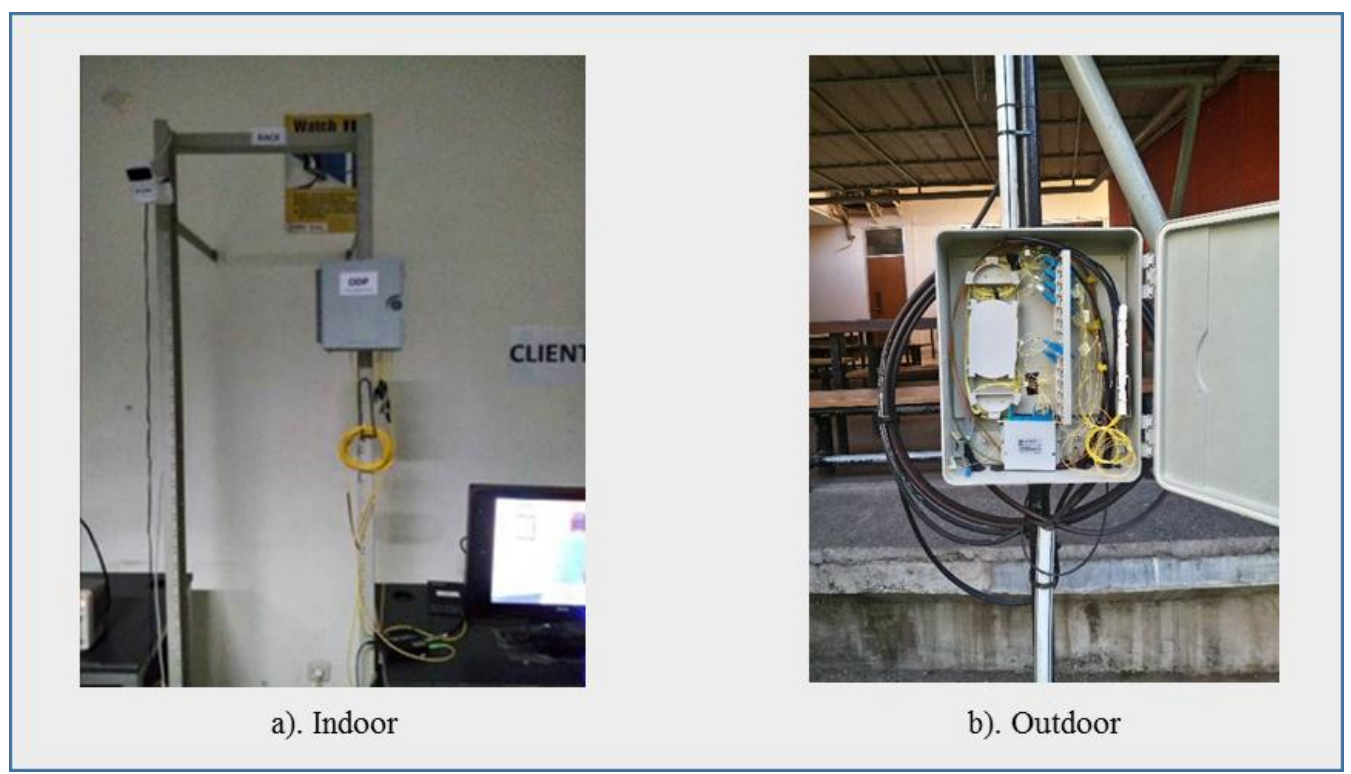

Gambar 6. ODC

Pada ODC terdapat passive splitter 1:8 yang akan membagi kapasitas kabel menjadi beberapa output. Letak ODC disesuaikan dengan letak ruang panel untuk mempermudah penarikan kabel, perawatan, serta maintenance. 
Pada implementasi ini Fiber Node berada di Laboratorium SKO yang terdapat perangkat OLT dan jaringan FTTH yang dikonvergensikan dengan HFC. Gambar letak fiber node dapat dilihat pada Gambar 7.

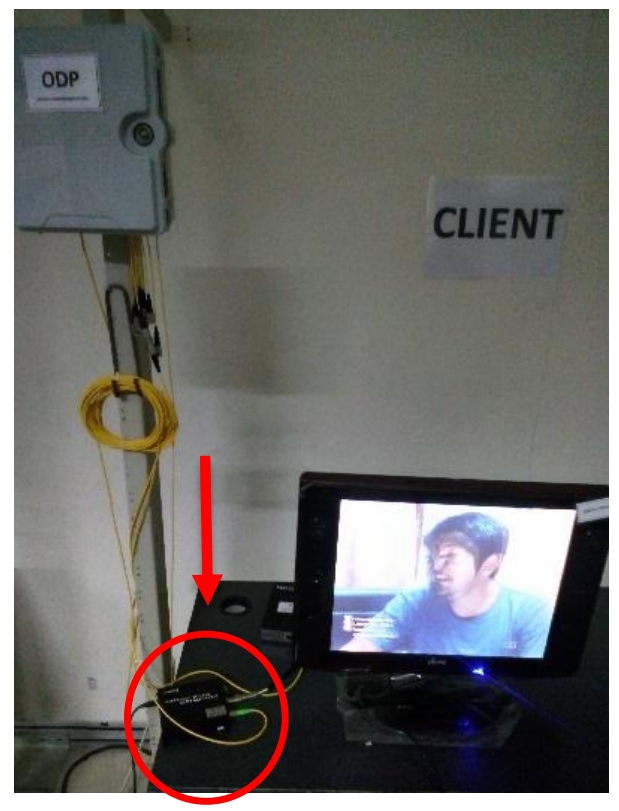

Gambar 7. Letak Fiber Node

\subsection{Pengujian Sistem}

Untuk mengetahui kualitas siaran tv yang dihasilkan, akan dilakukan beberapa skenario pengujian, antara lain:

1. Pointing antenna diarahkan ke Stasiun Relay Parongpong dengan jarak 19, $21 \mathrm{~km}$ dari antena penerima. Terminasi jaringan HFC dilakukan tanpa adanya input dari OLT FTTH.

2. Pointing antenna diarahkan ke Stasiun Relay Parongpong dengan jarak 19, $21 \mathrm{~km}$ dari antena penerima.Terminasi jaringan HFC dilakukan dengan input dari OLT FTTH.

3. Pointing antenna diarahkan ke Stasiun Relay Dangiang dengan jarak 45, $92 \mathrm{~km}$ dari antena penerima. Terminasi jaringan HFC dilakukan tanpa adanya input dari OLT FTTH.

4. Pointing antenna diarahkan ke Stasiun Relay Dangiang dengan jarak 45,92 km dari antena penerima.Terminasi jaringan HFC dilakukan dengan input dari OLT FT

Pengujian ini dilakukan dengan menggunakan perangkat lunak Andoid Geocam, Compass Cordinate, dan Measure Distance (untuk pointing antena), Spectrum Analyzer, Optical Power Meter, Osciloskop dan TV.

\subsubsection{Pengukuran Power Receive}

Pengukuran Power Receive dilakukan untuk mengetahui daya keluaran yang dihasilkan masing-masing perangkat. Nilai dari power receive dapat menjadi acuan dalam sensitivitas penerimaan daya di Fiber Node, nilai power receive ini berpengaruh terhadap bekerja atau tidaknya layanan TV. Berdasarkaan tabel 2, menunjukkan bahwa pada pengujian 1 dan 2, penerimaan power antena sama yakni sebesar $-60 \mathrm{~dB}$, sedangkan pada pengujian 3 dan 4 , sebesar $-42,8 \mathrm{~dB}$. Pengaruh dari gain dari amplifier tidak terlalu signifikan yakni sebesar -10 dB. Sedangkan untuk seluruh pengujian, nilai Power Fiber Transmitter sampai dengan power di FTM memiliki nilai yang sama. Power pada coupler pengujian 1 dan 3 memiliki nilai sama yakni $-22.54 \mathrm{dBm}$, sedangkan pada 
pengujian 2 dan 4 sebesar -1,63 dBm. Pada sisi akhir power input ke Fiber Node yakni power di ODC jaringan indoor, output yang yang dihasilkan pada pengujian 1 dan 3 sebesar $-26,8 \mathrm{dBm}$, sedangkan pada pengujian 2 dan 4 sebesar $-6,77 \mathrm{dBm}$. Perubahan daya yang dipancarkan Fiber Transmitter sampai dengan FTM di G9 mengalami penurunan daya sebesar 9,47 dBm yang diakibatkan pengaruh dari jarak fiber optik dari ruangan E3 ke G9, redaman konektor dan redaman splitter.

Tabel 2. Pengujian Power Receive

\begin{tabular}{|l|c|l|l|l|l|l|l|l|}
\hline No & Pengujian & $\begin{array}{c}\text { Power } \\
\text { Antena } \\
(\mathrm{dBm})\end{array}$ & $\begin{array}{c}\text { Power } \\
\text { Amplifier } \\
(\mathrm{dB})\end{array}$ & $\begin{array}{c}\text { Power } \\
\text { Fiber } \\
\text { Tx } \\
(\mathrm{dBm})\end{array}$ & $\begin{array}{c}\text { Power } \\
\text { FO HFC } \\
\text { ODC } \\
\text { port 7 } \\
(\mathrm{dBm})\end{array}$ & $\begin{array}{c}\text { Power } \\
\text { FO } \\
\text { HFC } \\
\text { FTM } \\
\text { G9 } \\
(\mathrm{dBm})\end{array}$ & $\begin{array}{l}\text { Power } \\
\text { Coupler } \\
(\mathrm{dBm})\end{array}$ & $\begin{array}{c}\text { Power } \\
\text { ODC } \\
\text { jaringan } \\
\text { dalam } \\
(\mathrm{dBm})\end{array}$ \\
\hline 1 & 1 & -60 & -50 & $-7,32$ & $-11,79$ & $-16,79$ & -22.54 & -26.8 \\
\hline 2 & 2 & -60 & -50 & $-7,32$ & $-11,79$ & $-16,79$ & -1.63 & -6.77 \\
\hline 3 & 3 & $-42,8$ & $-32,8$ & $-7,32$ & $-11,79$ & $-16,79$ & -22.54 & -26.8 \\
\hline 4 & 4 & $-42,8$ & -32.8 & $-7,32$ & $-11,79$ & $-16,79$ & -1.63 & -6.77 \\
\hline
\end{tabular}

Pada implementasinya, nilai power di ODC jaringan dalam harus memenuhi nilai sensitivitas detektor berdasarkan ITU-T sebesar -10 sampai dengan -28 dBm. Hasil uji kinerja dapat dilihat pada tabel 3 yang menunjukkan Output TV berdasarkan power receive antena. Berdasarkan tabel 3, pada pengujian 1 dan 3, nilai power input Fiber Node sebesar -26.8 dBm dapat memenuhi kinerja layanan TV HFC dan sensitivitas kinerja dari FTTH. Sedangkan pada pengujian 2 dan 4, nilai power input Fiber Node sebesar $-5.77 \mathrm{dBm}$ dapat memenuhi kinerja layanan TV HFC namun tidak memenuhi standar sensitivitas kinerja dari detektor. Maka untuk dapat memenuhi sensitivitas detektor, perlu ditambahkan splitter 1x8 (redaman 11dBm) dengan perhitungan akhir daya menjadi $-16,77 \mathrm{dBm}$.

Tabel 3 Hasil Uji Kinerja

\begin{tabular}{|c|c|c|l|}
\hline Pengujian & $\begin{array}{c}\text { Nilai Power Input } \\
\text { Fiber Node }\end{array}$ & $\begin{array}{c}\text { Kinerja layanan TV } \\
\text { HFC }\end{array}$ & \multicolumn{1}{|c|}{$\begin{array}{c}\text { Pemenuhan sensitivitas FTTH (-10 } \\
\text { sampai dengan -28) }\end{array}$} \\
\hline 1 & $-26,8 \mathrm{dBm}$ & Aktif & Memenuhi \\
\hline 2 & $-5,77 \mathrm{dBm}$ & Aktif & Tidak memenuhi \\
\hline 3 & $-26,8 \mathrm{dBm}$ & Aktif & Memenuhi \\
\hline 4 & $-5,77 \mathrm{dBm}$ & Aktif & Tidak memenuhi \\
\hline
\end{tabular}

Berdasarkan hasil pengujian yang ditujukkan pada tabel 4, Nilai yang dapat mempengaruhi kualitas gambar TV adalah besarnya penerimaan daya di antena. Semakin besar power yang diterima, maka semakin jernih kualitas tayangan yang dihasilkan. 
Tabel 4. Output TV

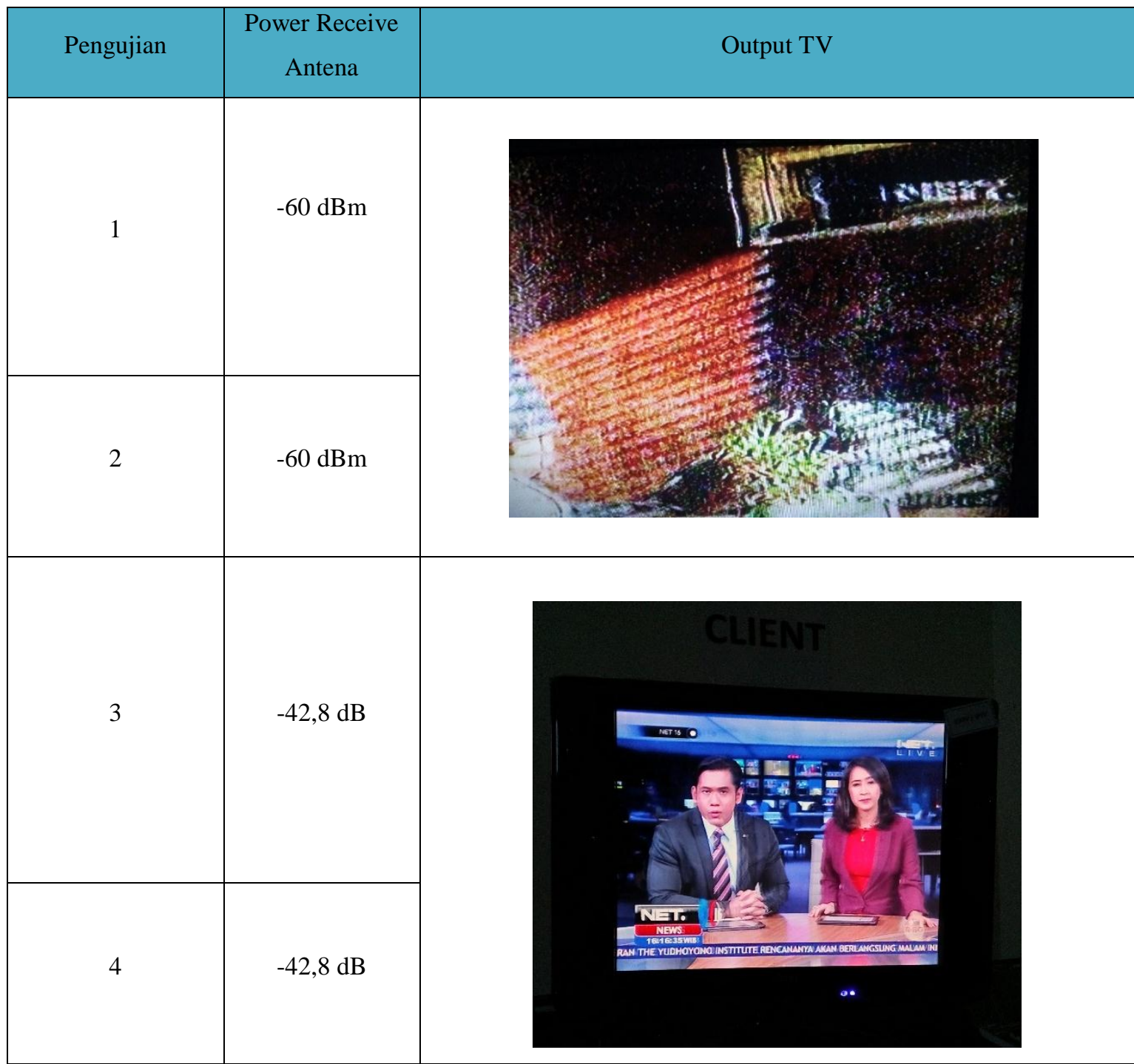

\subsubsection{Parameter CNR}

Parameter Kelayakan CNR merupakan parameter yang mendukung terharap nilai kualitas jaringan yang telah dibangun. CNR yang diukur merupakan nilai yang dapatkan berdasarkan pengukuran rasio nilai carrier dan nilai noise yang terdapat pada jaringan HFC yang telah diintegrasikan pada FTTH. Nilai CNR diperoleh melalui pengukuran menggunakan alat Oscilloscope dan Function Generator sebagai pembangkit sinyal carrier. Nilai yang diukur adalah nilai Video Bandwidth dan Noise Bandwidth dari pengujian Skenario Pengujian 4 yang telah diintegrasikan dengan FTTH. Hasil pengukuran didapatkan nilai video bandwidth sebesar $109 \mathrm{kHz}$ dan noise bandwidth sebesar $97.3 \mathrm{kHz}$. Dari perhitungan matematis menggunakan persamaan 1 dan 2 didapatkan CNR sebesar $47.7 \mathrm{~dB}$. Maka didapatkan nilai perbandingan pada tabel 5.

Tabel 5. Perbandingan Hasil CNR

\begin{tabular}{|c|c|c|}
\hline \multicolumn{2}{|c|}{ Rekomendasi Nilai HFC } & Nilai Hasil Pengukuran \\
\hline $\begin{array}{c}47 \text { sampai dengan } 49 \\
\mathrm{~dB}\end{array}$ & $\begin{array}{c}\text { ITU-T } \\
\geq 43 \mathrm{~dB}\end{array}$ & $47.7 \mathrm{~dB}$ \\
\hline
\end{tabular}


Tabel 5 menunjukkan bahwa nilai CNR yang didapatkan telah sesuai dengan standar yang diinginkan. Nilai CNR tersebut menunjukkan bahwa jaringan yang telah dibangun memiliki kualitas yang baik untuk mendukung layanan TV.

\subsubsection{Kapasitas Pelanggan}

Pengujian kapasitas pelanggan dilakukan untuk meghitung kapasitas pelanggan yang dapat digunakan pada jaringan HFC yang telah diintegrasikan pada FTTH. Kapasitas pelanggan yang diukur merupakan nilai yang didapatkan dari kalkulasi jumlah pelanggan tiap output segmen distribusi (setelah output coupler 2:1). Pengujian dilakukan pada skenario pengujian 1 dan 3 tanpa integrasi FTTH, serta pengujian 2 dan 4 dengan integrasi pada FTTH. Hasil pengujian kapasitas pelanggan dapat dilihat pada tabel 6 .

Tabel 6. Kapasitas Pelanggan

\begin{tabular}{|c|c|c|c|c|c|c|c|}
\hline \multirow[b]{2}{*}{ No } & \multirow{2}{*}{\multicolumn{2}{|c|}{ Pengujian }} & \multicolumn{4}{|c|}{ Penggunaan Perangkat Distibusi } & \multirow[b]{2}{*}{ Kapasitas total } \\
\hline & & & $\begin{array}{l}\text { ODC (sp } \\
1 \times 4)\end{array}$ & $\begin{array}{l}\text { ODP } \\
(\mathrm{sp} \\
1 \times 8)\end{array}$ & $\begin{array}{l}\text { Fiber } \\
\text { Node }\end{array}$ & $\begin{array}{l}\text { Splitter } \\
\text { Amplifier } \\
(1 \times 4)\end{array}$ & \\
\hline 1 & \multicolumn{2}{|c|}{ Pengujian ke $1 \& 3$} & - & $\sqrt{ }$ & $\sqrt{ }$ & $\sqrt{ }$ & 32 pelanggan \\
\hline \multirow{2}{*}{2} & \multirow{2}{*}{$\begin{array}{l}\text { Pengujian } \\
\text { ke } 2 \& 4\end{array}$} & $\begin{array}{l}\text { Jaringan } \\
\text { FTTH } \\
\text { Dalam }\end{array}$ & $\sqrt{ }$ & $\sqrt{ }$ & $\sqrt{ }$ & $\sqrt{ }$ & 128 pelanggan \\
\hline & & $\begin{array}{l}\text { Jaringan } \\
\text { FTTH } \\
\text { Luar }\end{array}$ & $\sqrt{ }$ & $\sqrt{ }$ & $\sqrt{ }$ & $\sqrt{ }$ & 128 pelanggan \\
\hline
\end{tabular}

Tabel 6. menunjukkan bahwa pada pengujian 1 dan 3, menggunakan perangkat distribusi koaksial splitter amplifier 1x4, dan ODP dengan splitter 1x4. Pada pengujian tersebut, total kapasitas pelanggan yang dapat dilayani yakni sebanyak 32 pelanggan. Sedangkan pada pengujian 2 dan 4, perangkat distribusi yang digunakan yakni ODC 1x2, ODP 1x8, serta Splitter Amplifier 1x4. Pada pengujian 2 dan 4, terdapat 2 jalur distribusi yakni jaringan FTTH dalam dan jaringan FTTH luar, dengan total kapasitas pelanggan yang dilayani sebanyak 256 pelanggan.

\section{KESIMPULAN}

Berdasarkan hasil pengujian didapatkan nilai power input Fiber Node yang memenuhi kinerja layanan TV yakni sebesar $-5 \mathrm{dBm}$ sampai dengan $-27 \mathrm{dBm}$. Nilai CNR yang didapatkan sebesar 47,7 dB sehingga hasil pengukuran kualitas HFC pada jaringan FTTH adalah baik dan memenuhi standar. Dari hasil pengujian didapatkan nilai kapasitas pada jaringan HFC tanpa integrasi FTTH sebanyak 32 pelanggan, sedangkan pada jaringan HFC yang diintegrasikan pada FTTH memiliki kapasitas pelanggan yang lebih banyak yakni 256 pelanggan. 


\section{DAFTAR PUSTAKA}

[1] Hadi, Agus. 2015. Pengertian Kabel Jaringan Fiber Optik Beserta Kelebihan dan Kekurangannya. Tersedia di http://teknodaily.com/pengertian-kabel-jaringan-fiber-optikbeserta-kelebihan-kekurangannya/. Diakses pada 1 Desember 2016

[2] Ovum report.2016. HFC: Delivering Gigabit Broadband. [Online]. Tersedia di : http://www.nbnco.com.au/content/dam/nbnco2/documents/HFC\%20Delivering\%20Gigabit $\% 20$ Broadband\%20Ovum\%20Report.pdf [diakses pada 9 juli 2018]

[3] D.J.Rice. 2015. DOCSIS 3.1 ${ }^{\circledR}$ Technology and Hybrid Fiber Coax for Multi-Gbps Broadband. Optical Fiber Communications Conference and Exhibition (OFC), Los Angeles, CA. 1-4.

[4] Damayanti. Tri Nopiani, Putri. Hasanah.2016. Perbandingan Unjuk Kerja Transmisi Jaringan FTTB Menggunakan GEPON dan GPON. Jurnal Elektro dan Telekomunikasi Terapan (JETT). 3:2 356-368.

[5] F. Phillipson. 2015. Estimating FTTH and FTTCurb Deployment Costs Using Geometric Models with Enhanced Parameters. 20th European Conference on Networks and Optical Communications - (NOC), London. 1-5.

[6] R. Jirachariyakool, N. Sra-ium and S. Lerkvaranyu. 2017. Design and Implement Of GPON-FTTH Network For Residential Condominium. 14th International Joint Conference on Computer Science and Software Engineering (JCSSE). 1-5.

[7] M. Żotkiewicz and M. Mycek. 2017. Reducing the Costs Of FTTH Networks By Optimized Splitter And OLT Card Deployment. IEEE/OSA Journal of Optical Communications and Networking. 9: 5 412-422.

[8] Ahmad, S. S., Aplikasi HFC untuk Layanan Dua Arah, Gematel Nomor 2/XXVIII

[9] Siswantha, Hendrico.2005. Analisa Headend pada Jaringan HFC Hybrid Fiber Coax Untuk Mendukung Layanan Multimedia di Jakarta. Skripsi, Universitas Telkom: Bandung.

[10] Wavelenght Division Multiplexing. Universitas Mercubuana : Jakarta. Tersedia di digilib.mercubuana.ac.id/manager/n!@file_skripsi/Isi3516031286529.pdf. Diunduh pada : 1 Agustus 2017

[11] T. Rokkas, I. Neokosmidis, D. Katsianis and D. Varoutas. 2012. Cost Analysis of WDM and TDM Fiber-to-the-Home (FTTH) Networks: A System-of-Systems Approach.in IEEE Transactions on Systems, Man, and Cybernetics, Part C (Applications and Reviews). 42:6 1842-1853. 